\title{
THE ROLE OF HIV/AIDS COMMITTEE AT HKBP BALIGE HOSPITAL IN HIV/AIDS CONTROL AND PREVENTION IN TOBA SAMOSIR, NORTH SUMATERA
}

\author{
Martinus Sudianto Tambunan
}

\author{
Masters Program in Public Health, Universitas Sumatera Utara
}

\begin{abstract}
Background: There were approximately 36.7 million people worldwide living with HIV/AIDS at the end of 2016. Of these, 2.1 million were children $(<15$ years old). An estimated 1.8 million individuals worldwide became newly infected with HIV in 2016 about 5,000 new infections per day. This study aimed to evaluate the role of HIV/AIDS committee at HKBP Balige hospital in HIV/AIDS control and prevention in Toba Samosir, North Sumatera.

Subjects and Method: This was a qualitative study conducted at HKBP Balige Hospital, Toba Samosir, North Sumatera. Several key informants were selected from HIV/AIDS committee, religious leaders, health practitioners, health promotion staff, and people living with HIV/AIDS. The dependent variable was HIV/AIDS control and prevention. The independent variable was HIV/AIDS committee. The data were collected by in-depth interview, focus group discussion, and document review. The data were analyzed by content analysis.

Results: HIV/AIDS Committee of HKBP Balige had played its important role in several collaborative initiatives: (1) Socialization of HIV/AIDS control and prevention measures with the assistance of religious groups; (2) Mental and religious coaching; (3) Basic HIV and AIDS Counseling; (4) Healthy Life Campaign; (5) HIV/AIDS Mobile Clinics to places with high potential of transmission; (6) Social assistance and rehabilitation.

Conclusion: HIV/AIDS Committee of HKBP Balige has played its important role in several collaborative HIV/AIDS control and prevention initiatives in North Sumatera.
\end{abstract}

Keywords: HIV/AIDS Committee, HIV/AIDS control and prevention.

\section{Correspondence:}

Martinus Sudianto Tambunan. Masters Program in Public Health, Universitas Sumatera Utara, North Sumatera. Email: martinusstbn@yahoo.com.

Mobile: 08216501r844. 